Correction

\title{
Correction: Aboelnga, et al. Urban Water Security: Definition and Assessment Framework. Resources 2019, 8, 178
}

\author{
Hassan Tolba Aboelnga 1,2,*(D), Lars Ribbe ${ }^{2}\left(\mathbb{D}\right.$, Franz-Bernd Frechen ${ }^{1}$ and Jamal Saghir ${ }^{3}$ \\ 1 Department of Sanitary and Environmental Engineering (DESEE), University of Kassel, Kurt-Wolters-Str. 3, \\ 34125 Kassel, Germany; frechen@uni-kassel.de \\ 2 ITT, Cologne University of Applied Sciences, Betzdorfer Str. 2, 50679 Cologne, Germany; \\ lars.ribbe@th-koeln.de \\ 3 Institute for the Study of International Development, Peterson Hall, McGill University, 3460 McTavish Street, \\ Montreal, QC H3A 0E6, Canada; jamal.saghir@mcgill.ca \\ * Correspondence: haboelng@th-koeln.de
}

check for

updates

Citation: Aboelnga, H.T.; Ribbe, L.; Frechen, F.-B.; Saghir, J. Correction: Aboelnga, et al. Urban Water Security: Definition and Assessment Framework. Resources 2019, 8, 178. Resources 2021, 10, 92. https:// doi.org/10.3390/resources10090092

Received: 30 August 2021

Accepted: 2 September 2021

Published: 14 September 2021

Publisher's Note: MDPI stays neutral with regard to jurisdictional claims in published maps and institutional affiliations.

Copyright: (C) 2021 by the authors. Licensee MDPI, Basel, Switzerland. This article is an open access article distributed under the terms and conditions of the Creative Commons Attribution (CC BY) license (https:// creativecommons.org/licenses/by/ $4.0 /)$.
The authors wish to make the following corrections to this paper [1]:

In Section 2.2 Working Definition of Urban Water Security:

"There is no widely recognized definition of urban water security [31]. In terms of widely-referenced definitions (Table 1), a recent review has identified 25 definitions of water security, of which only three relate to the urban level [73]" should be revised as "There is no widely recognized definition of urban water security [31,32,37,39,44,73]. In terms of widely-referenced definitions (Table 1), a recent review has identified 25 definitions of water security, of which only three relate to the urban level [31]".

The authors would like to apologize for any inconvenience caused to the readers by the change. The change does not affect the scientific results. The manuscript will be updated, and the original will remain online on the article webpage, with a reference to this correction.

\section{Reference}

1. Aboelnga, H.T.; Ribbe, L.; Frechen, F.-B.; Saghir, J. Urban Water Security: Definition and Assessment Framework. Resources 2019, 8, 178. [CrossRef] 